\title{
Trivial Objects from Taishō Japan in the Collection of Alma M. Karlin
}

\author{
Chikako SHIGEMORI BUČAR*
}

\begin{abstract}
Alma M. Karlin, a young woman adventurer who made her journey around the world between 1919 and 1927, stayed in Japan for a little more than a year. As a young woman without significant funds, she relied on her own ability to earn a living during her stay in the country. Among the items she brought back from Japan to Slovenia there are many small objects which are not typical "exotic objects from the Far East". They are rather small and trivial items such as a wall calendar, a streetcar ticket, children's miniature toys, a part of ceremonial wrappings, and paper bookmarks. This paper focuses on the small and untypical items Karlin brought back from Japan. Karlin's travelogue and other writings, including her notes on the unused postcards, give us some information about her life in Japan. Together with her travelogue, notes and messages on the objects in her legacy, we can reconstruct some aspects of her everyday life in Japan. Though small and trivial, such items collected by Karlin reveal some important details of her experience in the central part of Tokyo in the Taishō period.
\end{abstract}

Keywords: trivial objects, Alma M. Karlin, Taishō Japan, collecting, souvenir

\section{Trivialni predmeti z Japonske v obdobju Taishō v zbirki Alme M. Karlin Izvleček}

Alma M. Karlin je potovala okoli sveta med letoma 1919 in 1927. Na Japonskem je živela nekaj več kot eno leto. Med predmeti, ki jih je prinesla domov z Japonske, je kar nekaj drobnarij, ki niso tipični »eksotični predmeti z Daljnega vzhoda«. So majhni in trivialni predmeti, npr. stenski koledarček, vozovnica za tramvaj, otroška miniaturna kuhinjica, vrvice za zavijanje daril in papirnata bralna znamenja. Clanek opiše in analizira te drobne in netipične spominke v zbirki Alme Karlin. Skupaj z njenim potopisom in zapiski ter kratkimi beležkami na hrbtnih straneh razglednic nam ti predmeti razkrivajo podrobnosti njenega življenja na Japonskem, ki ga je večinoma preživela v središču Tokia v obdobju Taishō.

Ključne besede: drobni predmeti, Alma M. Karlin, obdobje Taishō, zbiranje, spominki

Chikako SHIGEMORI BUČAR, Associate Professor of Japanese

Studies, Faculty of Arts, University of Ljubljana.

Email address: chikako.shigemoribucar@ff.uni-lj.si

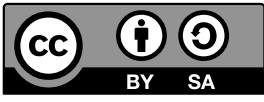




\section{Introduction}

Alma M. Karlin, a young woman adventurer from a small Slovenian town in the newly founded Kingdom of Serbs, Croats and Slovenes (the former Austria-Hungarian Empire), made her journey around the world between 1919 and 1927. She stayed in Japan for a little more than a year, from June 1922 to July 1923 (the 11th and 12th years of Taishō). As a young woman without significant funds, she relied on her own language abilities to earn a living during her stay in Japan as a writer and correspondent, and sometimes as language teacher, translator and embassy worker. Among the items she brought back to Slovenia, inventoried in the Regional Museum Celje, there are certainly some typical "exotic objects from the Far East" such as lacquerware, ukiyo-e prints, and fans. However, many of the Japanese objects archived as Karlin's legacy in the museum are rather small and trivial, such as a wall calendar, tram ticket, miniature toys, towels, parts of ceremonial wrappings, paper bookmarks, and picture postcards. We would certainly not define them as "art objects", but rather as "souvenirs" or "memorabilia".

It is true that Karlin was financially limited and thus could not purchase fancy and expensive furniture or ceramics, but she carefully collected small items which would be insignificant for most Western collectors, and this article closely analyses some of these objects from Japan. Though small and trivial, these items reveal some important details of her experience in Japan and the life in the central part of Tōkyō in the Taishō period (1912-1926) ${ }^{1}$. Based on these objects and her extraordinary interest in seeming trivialities, we can ask ourselves how we judge "ethnological interest" and curiosity of the "Westerner" in the first decades of the 20 th century in the context of East-West exchanges.

In the first part of the paper, Karlin's intention for her journey is reviewed, in order to subsequently answer the question of how she imagined and wished to make her own collection of objects. In the following part, some theories on "collecting" are introduced with the main focus on "souvenirs". What are souvenirs and what do souvenirs mean to the collector? What do these objects mean to other people around the collector, and the later viewers of the objects, the museum visitors and curators? In the main body of this paper, the small trivial objects from Japan in Karlin's collection are closely analysed together with the additional information found in Karlin's travelogue and other sources. In conclusion, the true value of "insignificant and trivial" objects from the Taishō Japan is explained.

1 For more about the Taishō period see Shigemori Bučar (2019, 7-9). 


\section{Living and Collecting in Japan}

Japan was the country that Karlin dreamt of going to, even before setting out for her long journey around the world (Trnovec 2019, 8). During her study years in London between 1908 and 1914, she made some acquaintance with individuals from Japan, China, India, and so on, to whom she gave some language lessons. According to Trnovec $(2011,19)$, Karlin stayed in London and was active as an instructor and translator of German in the City School of Languages in Ealing between October 1909 and April 1911. Some exhibitions in the major British museums attracted her attention, particularly those about less known peoples and cultures, such as the Ainu of the northern part of Japan and Taiwanese indigenous peoples. ${ }^{2}$ The Regional Museum Celje holds two postcards with the caption "Ainu Home, Japan-British Exhibition". Both postcards were actually used by Karlin for correspondence with her mother during this study period, addressed to "Frau Major Karlin, Cilli, Austria”. The Japan-British Exhibition (日英博覧会, Nichi-Ei Hakuran-kai) took place at Shepherd's Bush in London from May 14th to October 29th, 1910. It was a large international exposition, driven by the desire of Japan to develop a more favourable public image in Britain and Europe following the renewal of the Anglo-Japanese Alliance in 1902. Japan intended to display the country's new status as a great power by emphasising its role as a colonial power in Asia (Yamaji 2009/2010, 2-4).

Karlin, after her subsequent study years in Oslo and Stockholm, and a period of intensive language teaching in her hometown of Celje, was finally prepared for her journey around the world towards the end of 1919. At this preparational stage, she had already acquired a visa to enter Japan (Trnovec 2011, 22-24). Due to various difficult circumstances, she succeeded in arriving in Japan three years after her departure from her hometown. Already in the first part of her journey around the world, she experienced hardships, including a lack of finances. In Peru she was physically attacked several times, and when she arrived in Panama, she had no money and had to borrow some from the American Red Cross (ibid., 31). After traveling from the Central American countries to California and Hawaii, Alma Karlin finally arrived in Japan, in Yokohama, and resided in the central part of the city of Tokyo (Shigemori Bučar 2019, 12).

Karlin's travelogues are not strict records of facts, but often rather dreamy and impressionistic notes on her miscellaneous discoveries and encounters during her stays in foreign environments. All the same, we can read interesting details of her life in these, and in particular in a short part of her travelogue, some 40 pages, about Japan (Karlin 2006, 225-70). We can also imagine some additional elements of her life

2 For more on Alma Karlin and Taiwanese indigenous peoples see Veselič (2021). 
in Japan through her notes on the backs of postcards and so on (Shigemori Bučar 2019, 3).

\section{Collections, Souvenirs and Beyond}

Alma Karlin's collecting activity was motivated by her longing to travel, her researching spirit and urge to learn. She wished to know distant parts of the world, discover and learn from them. She also dreamt of all things she could possibly bring home to form her own collection (Trnovec 2020, 63). According to Trnovec, the collecting activity of Alma Karlin was, due to the special circumstances she travelled under, not very systematic, but rather random and by chance. Her collection came into being in three main ways: 1 . purchased, 2 . collected by herself, 3. received as gifts. (ibid., 66, 72) Though it may have been less systematic in comparison to some other East Asian collections of Westerners, Karlin's collection, viewed today, after almost 100 years, is interesting to our eyes.

The activity of collecting is defined, for example, by Belk as: "The process of actively, selectively, and passionately acquiring and possessing things removed from ordinary use and perceived as part of a set of non-identical objects or experiences." (Belk 2006, 535)

Pearce (1994, 157-58), while admitting the fact that definitions tend to be self-serving and circular, gives some earlier definitions of "collecting": W. Durost, according to Pearce "one of the earliest students of collecting", stated in 1932 that a collection is determined by the nature of the value assigned to the objects, or ideas possessed; J. Alsop $(1982,70)$ stressed the mentality of the collector, saying "to collect is to gather objects belonging to a particular category the collector happens to fancy."; N. Aristides $(1988,330)$ "collection [is] an obsession organised". Pearce, considering Belk's definition cited above, stresses the essentially subjective element in collecting, the mentality of the collector who decides to include certain objects in his/her collection in a certain organised way. The time of Karlin's journey was relatively late in comparison with other Westerners' who collected Asian and Japanese exotic items (Shigemori Bučar 2020b, 91-92, 95-96), but a bit early to discuss in the context of the ethnology of collecting.

Veselič (2021 [forthcoming]) discusses the nature of Karlin's collected objects, noting that "... there are hardly any objects that would be considered representative collectors' items at that time." It is true that many of these objects are in between "the divide between collectibles and souvenirs." The distinction between "collectibles" and mere "souvenirs" may sometimes become very subtle, and seems to vary according to their spatial and temporal backgrounds. 
If we turn to discussion about souvenirs, we find that collecting, or the random choice of items from visited places, is universal and yet personal, interwoven with the way we, the collectors, all try to make sense of the world, and our place in it (Potts 2018, xviii). A souvenir is a personal reassurance. When we travel to distant places, we collect "interesting" objects with which we identify ourselves.

[...] as travelers, we are by definition itinerant outsiders—-strangers in strange lands-who don't possess the experience or knowledge to objectively evaluate the things we see along the way. When we collect souvenirs, we do so not to evaluate the world, but to narrate the self. (ibid., 94)

Karlin wanted to "discover", and the objects she brought home were the existential authenticity of the Other, and of herself. Seemingly small and unimportant items, together with some written information and notes, give us additional clues not only about the collector's presence at the time of acquirement of the object, but also often about the collector's attitude towards the collected object. The writing may often relate to another object or person, or activity and event, so that we may reconstruct the environment of the collector and his/her activity.

In case of Alma Karlin, she left us her travelogues and other writings in which she describes her experience during her journey. Based on her writings and earlier research about her (Stanonik 1983; Trnovec 2011), it has become known to us that Karlin stayed in Japan between June 1922 and July 1923, and that she resided in Tokyo for the most of her time in the country, and travelled through the southwestern part of Japan to depart for the Korean peninsula. The Japanese objects in her legacy are thus placed in the time period of the years 11 and 12 of the Taishō period in Japan. Based on these objects, we have also reconstructed some of her visits to temples and shrines, and certain important places for her life in Tokyo. An interview with Karlin, published in a Japanese newspaper, also helped locate her whereabouts in Tokyo (Shigemori Bučar 2019; Shigemori Bučar 2020a).

The following part of this paper introduces some "insignificant" and small Japanese objects in Karlin's legacy in the Regional Museum Celje. Some of these items have been introduced already in the exhibition in 2019 and individual studies, ${ }^{3}$ but some additional details are given here. A particular focus is on some other small items which are taken up in this paper for the first time. They are divided into the following eight types: a) new-year greeting card; b) receipt issued by a newspaper company; c) miniature toy kitchen; d) gift wrappings; e) wooden box cover; f) paper bookmarks; and g) envelopes for postcard sets. For

3 For a thorough analysis of an ink stone from Alma Karlin collection, see Berdajs (2019). 
each type, wherever possible, some explanation in relation to the Japanese culture and tradition are given, and sometimes in relation to the historical characteristics of the Taishō period.

Based on the detailed analysis of these small and trivial objects, an attempt is made to interpret the characteristics of Karlin's collecting and her "ethnological interest", which presupposes her further intention, partly perhaps not realised due to the later circumstances of her life.

\section{Small and "Trivial" Objects}

In the exhibition in Celje in 2019 entitled "Asia Utterly Bewitched Me" (Trnovec et al. 2019), various objects brought back by Alma Karlin were introduced to the public. Among the Japanese items, there were smaller, singular objects such as a wall calendar, a tram ticket, and items of miniature toys next to more impressive lacquerware and ukiyo-e prints.

The small wall calendar shows the month of February, 1923, when Karlin was residing in Tokyo. The tram ticket is also a concrete proof that she used the transportation to go to her workplace, most probably the German Embassy. These objects support some facts mentioned in her writings, and more details about them are given in the following sections.

\section{a) A New Year Greeting-Card with Kewpies}

Among the numerous picture postcards in Karlin's archive in the Regional Museum Celje, ${ }^{4}$ there is one interesting, used postcard: this one is different from most of the picture postcards in the collection, because the front side shows a coloured drawing and not a photo of some tourist site or some Japanese curiosity, which is usually seen on other postcards in her collection. It is a sort of caricature, typical of the liberal Taishō period, an illustration of the originally American cupid figure, "Kewpie", created by Rose O'Neill (1874-1944), the comic-strip illustrator, and first shown in the American magazine Ladies Home Journal in 1909. O'Neill also made paper doll versions of the Kewpies. They were first produced as bisque dolls in Germany starting around 1912, and became extremely popular in the early 20th century (Digital Daiji-sen Plus 2019a; Shogakukan Random House Japanese-English Dictionary 2020).

4 Some of the numerous postcards in Karlin's collection in the Regional Museum Celje have been analysed by Shigemori Bučar (2016; 2019; 2020a), but some others still await closer analysis. 
In Japan, the Kewpie was also known as a plastic or a soft rubber doll for small children. Later, an entrepreneur established a mayonnaise factory with the brand name “Kiyūpī Mayonnaise キユーピー・マヨネーズ”, still known and used among Japanese even today (Digital Dai-ji-sen Plus 2019b).

The Postcard Museum in Kobe holds at least 15 postcards with similar drawings of Kewpies from the Taishō period. All of them are drawings in which some Japanese traditional custom is combined with this American figure. Some postcards in the Museum are also photographed Japanese girls playing with Kewpie dolls (Ehagaki Shiryōkan n.d.).

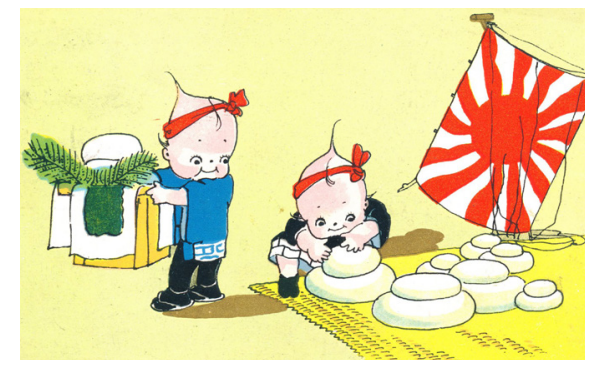

Figure 1. New-Year greeting card with Kewpies. (Source: Alma Karlin Collection, Celje Regional Museum)

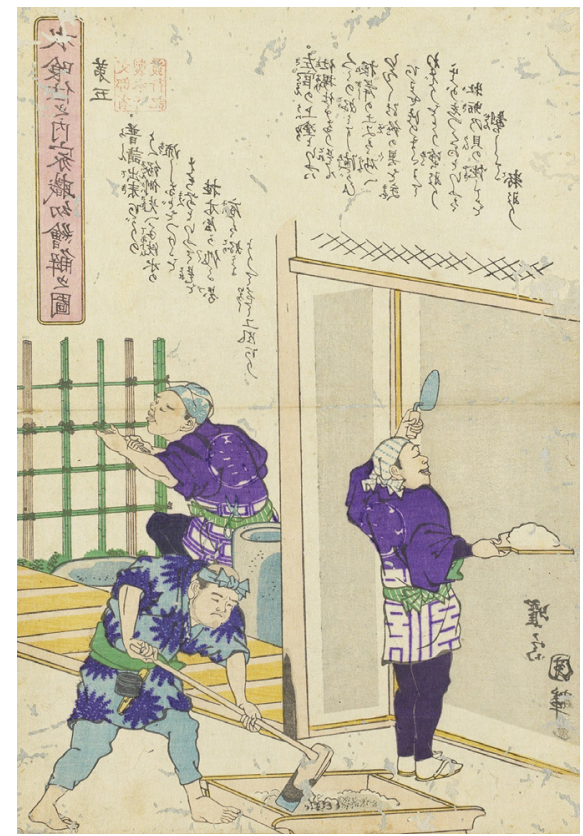

Figure 2. A Gardener and Plasterers. (Utagawa Kuniteru, National Institutes for the Humanities, https://ja.ukiyo-e.org/image/metro/086-006-23) 
The postcard considered here shows two cupids or "Kewpies" dressed in the style of traditional Japanese plastering workers (sakan'ya 左官屋). Sakan may be translated as "plasterer", originally the plasterer for palaces and villas of noble families in the Heian period (794-1185). Later, this naming started to be used for all professional building workers who are trained for plastering and making storehouses with thick mortar walls. The Kewpies on the postcard are typically dressed in tight trousers (momohiki 股引き), typical Japanese socks (tabi 足袋) and sandals (zōri 草 履), along with workers' jackets ( hanten 半䌕). Their depiction is very similar to the ukiyo-e sketch of sakan'ya from the Edo period (1603-1868) (fig. 2). Since Kewpie's hair is characteristic of the figure and cannot be covered by a Japanese towel (tenugui 手拭(), as in the ukiyo-e depiction of workers from the Edo period, the two Kewpies wear red headbands (bachimaki 鉢巻) around their heads. They are busy making the typical round rice cakes (kagamimochi 鏡餅), to be put onto the alcove in a Japanese room (tokonoma 床の間) or the entrance of a household (genkan 玄関) for the New Year. Behind the workspace on the right corner is a kite or the Rising Sun Flag (kyokujitsuki 旭日旗), the Japanese national flag of the time and the flag of the Imperial Japanese Navy. A straw mat (mushiro 莚) is spread over the right half of the ground where one of the Kewpies is stacking smaller mochi pieces on the bigger ones, while the other Kewpie is carrying the kagamimochi on the typical wooden square stand (sanbō 三宝), usually used for Shinto offerings. The kagamimochi ready to be carried to the right place is decorated together with the pine branches and a piece of sea tangle (konbu 昆布), both needed for the festivity to symbolise long life, on white pieces of paper, all symbolic for the New Year offering.

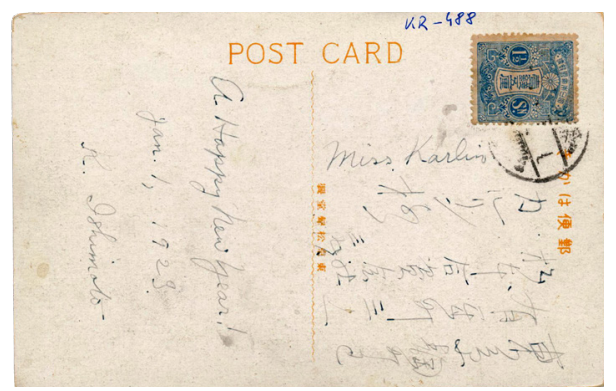

Figure 3. The reverse of the New-Year greeting card with Kewpies. (Source: Alma Karlin Collection, Celje Regional Museum)

On the reverse of this postcard (fig. 3) we see the handwritten address of 'Miss Karlin' in Tokyo, and a short message for the occasion in English: "A Happy New Year!, Jan. 1, 1923. K. Ishimoto”. A postage stamp of one and a half sen一銭五厘 
(issen gorin) is pasted in the corner. The postcard was sent within the country of Japan, which is also a rarity in Karlin's collection. In the collection, no other postcard has so far been found which was sent to her within the country of her residence.

The postal address is written in Japanese:

東京鈢町区有楽町三の1杉本合資会社三七 カルリン様 [=Ms Karlin, Sugimoto Co. Ltd. 37, 3-1 Yūraku-chō, Kōjimachi-ku, Tōkyô]

The ward Köjimachi-ku is today's Chiyoda-ku, in the central part of Tokyo.

We can imagine that Alma Karlin was living in some company's dormitory, and the number 37 is perhaps her room number. The sender of this postcard may be one of the language students to whom Alma Karlin was giving lessons. This postcard greeting is good proof that Karlin actually experienced New Year in Tokyo, when she was living at this address, and it was the time when she was giving English language lessons (Karlin 2006, 253-55).

\section{b) Receipt from the Newspaper House Tōkyō Nichinichi}

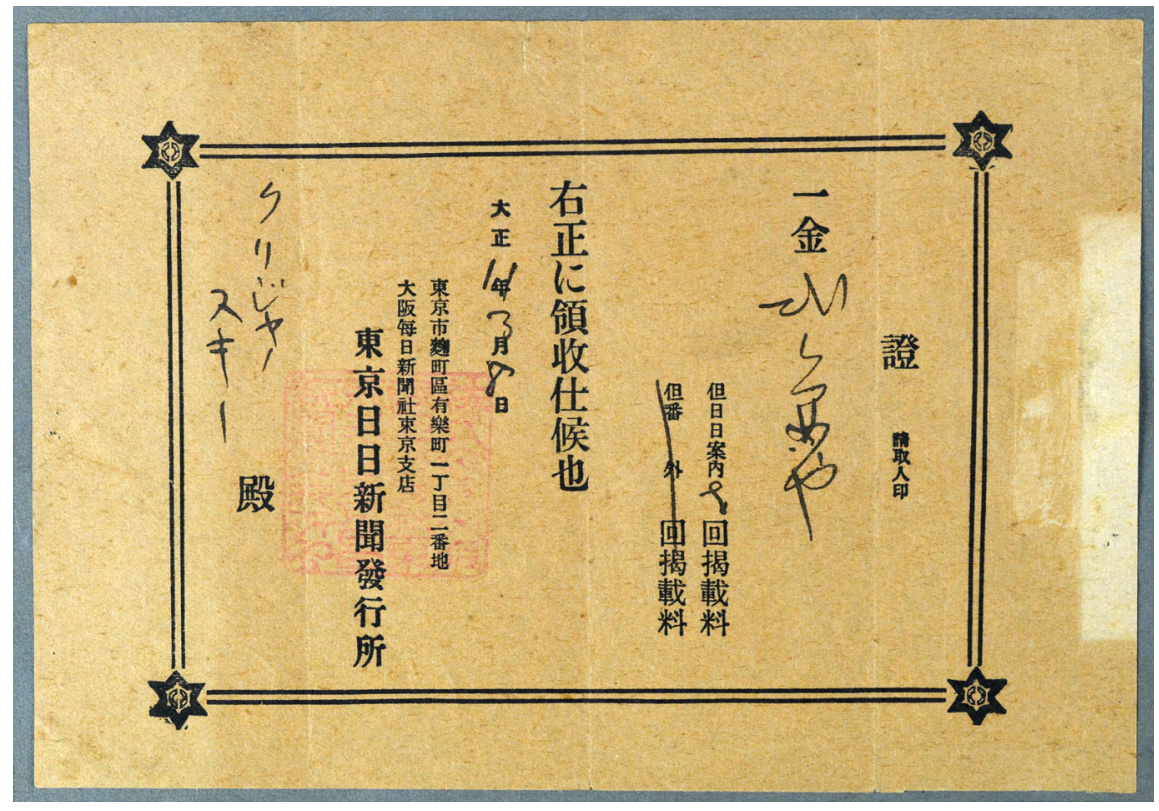

Figure 4. A receipt dated March 8th, 1922, by a newspaper company. (Source: Alma Karlin Collection, Celje Regional Museum) 
This piece of paper was archived together with other paper trifles in Karlin's legacy. The receipt was issued in March 1922 (the 11th year of Taishō) by the newspaper publishing office of the Tokyō Nichinichi Shinbun (former name of the Mainichi Shinbun, one of the largest newspapers in Japan even today). The printed and handwritten text on it reads:

[Certificate stamp of receipt

Amount: 20 yen

for placing 9 (?) times information/advertisement

for placing - times of extra articles

We have duly received the amount as above.

March 8th, Taishō 11

2, Yūrakuchō, Kōjimachi-ku, Tōkyō-shi

The Tōkyō Branch of the Ōsaka Mainichi Shinbun

The Publishing Office of the Tōkyō Nichinichi Shinbun

To: Mr/Ms Križanoski (?)]

We are yet to find out what payment it was and why this receipt was brought back by Alma Karlin to Slovenia. The date of issue is March 8th, 1922: maybe it was an advertisement by Alma Karlin for her further activities and plans, searching for a job using her language knowledge in order to save some more money for her further journey around the world. The receipt is addressed to some person with the name “Kuridžanosuki クリジャノスキー”, perhaps Križanoski or Križanovsky. This person most probably paid this sum instead of Alma Karlin, who perhaps later returned the money, thus this receipt ended up in Karlin's hands. To date, this name has not been found in Karlin's writings and we have no clue as to the meaning of this receipt.

We thus consider further why the receipt by the newspaper company is included in Karlin's legacy. The reason should be one of the following two: the payment was of a deciding importance for Karlin (supposedly made by Mr. or Ms. Križanovsky and later paid back by Karlin), or Karlin was interested in the written format of the receipt and asked to have the document so that she could include it in her collection. The second reason is weaker, because as far as we know Karlin never tried to learn the Japanese language. She was busy giving language lessons and never spoke or wrote in Japanese except for some basic nouns to name culturally specific objects and ideas.

\section{c) Miniature Toy Kitchen}

Karilin's collection also includes a very interesting miniature kitchen set. Individual kitchen items were inventoried as separate objects, but the research work revealed 
that some of them belong together and are parts of a miniature kitchen. ${ }^{5}$ According to the Director of the Toy Museum in Japan 日本玩具博物館, Inoue Shigeyoshi 井上重義, miniature kitchen sets were in fashion among the more privileged families in the Kansai area (the western part of the Honshu island, in and around the cities of Kyōto, Ōsaka and Kōbe) during the Meiji and Taishō periods up to the beginning years of Shōwa (Inoue Shigeyoshi, email correspondence, April 20th, 2019). The kitchen set was usually used together with the bina dolls for the March 3rd Girls' Festival. The bina dolls are usually exhibited in the family living space, and the daughters in the family and their female friends gather in front of the dolls for the festival. In certain regions of Japan the girls could also play with the miniature kitchen which was placed in front of the main decoration of bina dolls. It is assumed that these miniature kitchens were produced in Kyōto and Ōsaka, since they were mainly exhibited and used in the families of the Kyōto-Ōsaka area. Some pieces of this Japanese miniature kitchen, such as a wooden cupboard, a wooden container for cooked rice, and some plates, have already been introduced in the exhibition catalogue (Trnovec et al. 2019, 36). Additional identifying pieces of the miniature kitchen are the small stove for cooking with charcoal (shichirin 七輪) (fig. 5), the lid of a rice-cooking pot (the pot is usually made of iron and the lid is wooden with the particular handles on the top, shown upside down in the photo, figs. 6 and 7), and the pounding mallet for making rice cakes (kine 杵, fig. 8).

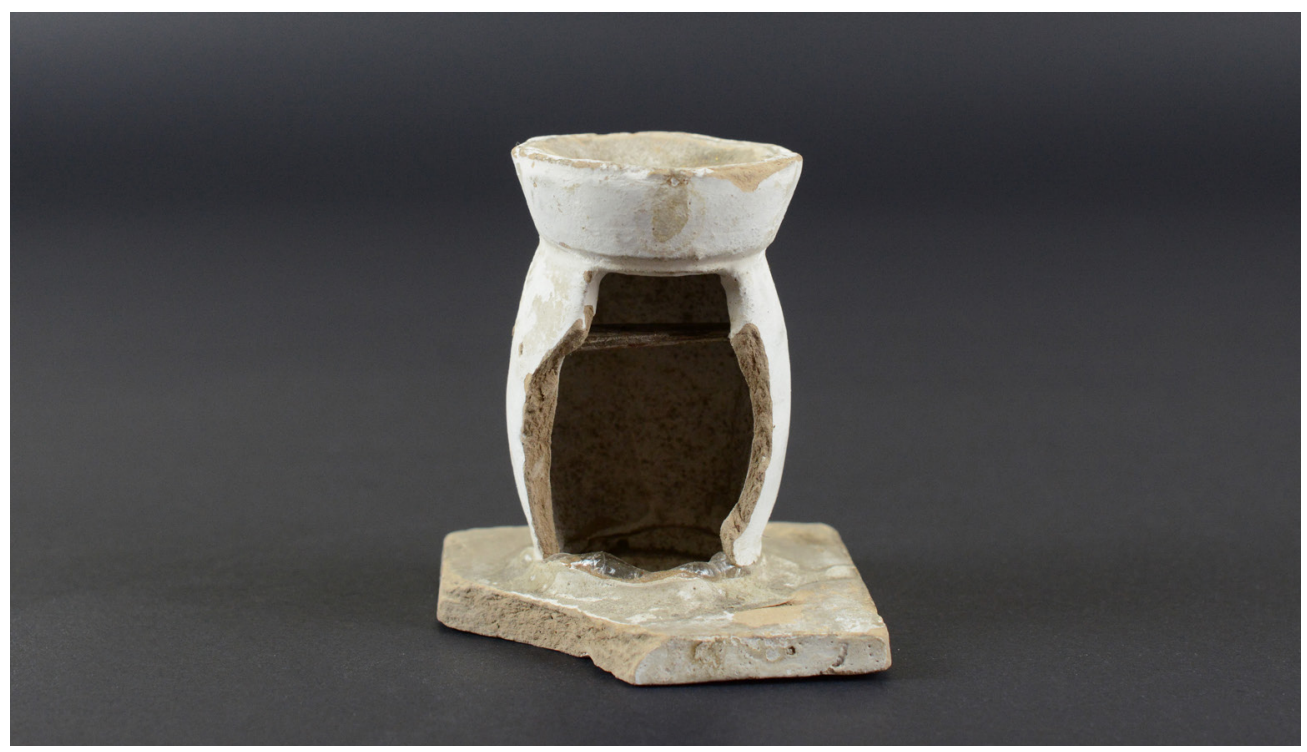

Figure 5. A miniature shichirin. (Source: Alma Karlin Collection, Celje Regional Museum)

5 I am grateful to Helena Motoh for pointing out the kitchen collections in the Toy Museum. 
Figure 6. A miniature pot lid. (Source: Alma Karlin Collection, Celje Regional Museum)

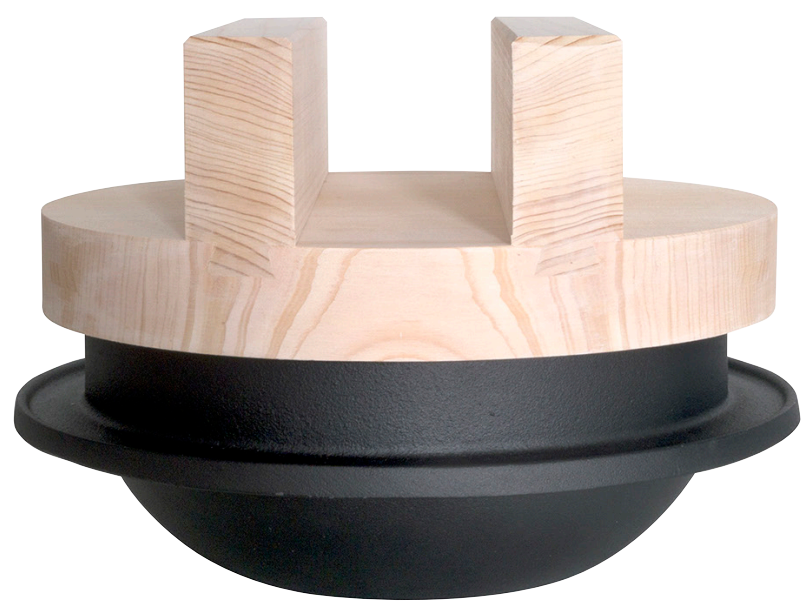

Figure 7. An old-style pot for cooking rice. (Source: http://www.kama-asa.co.jp/info/10076/) 


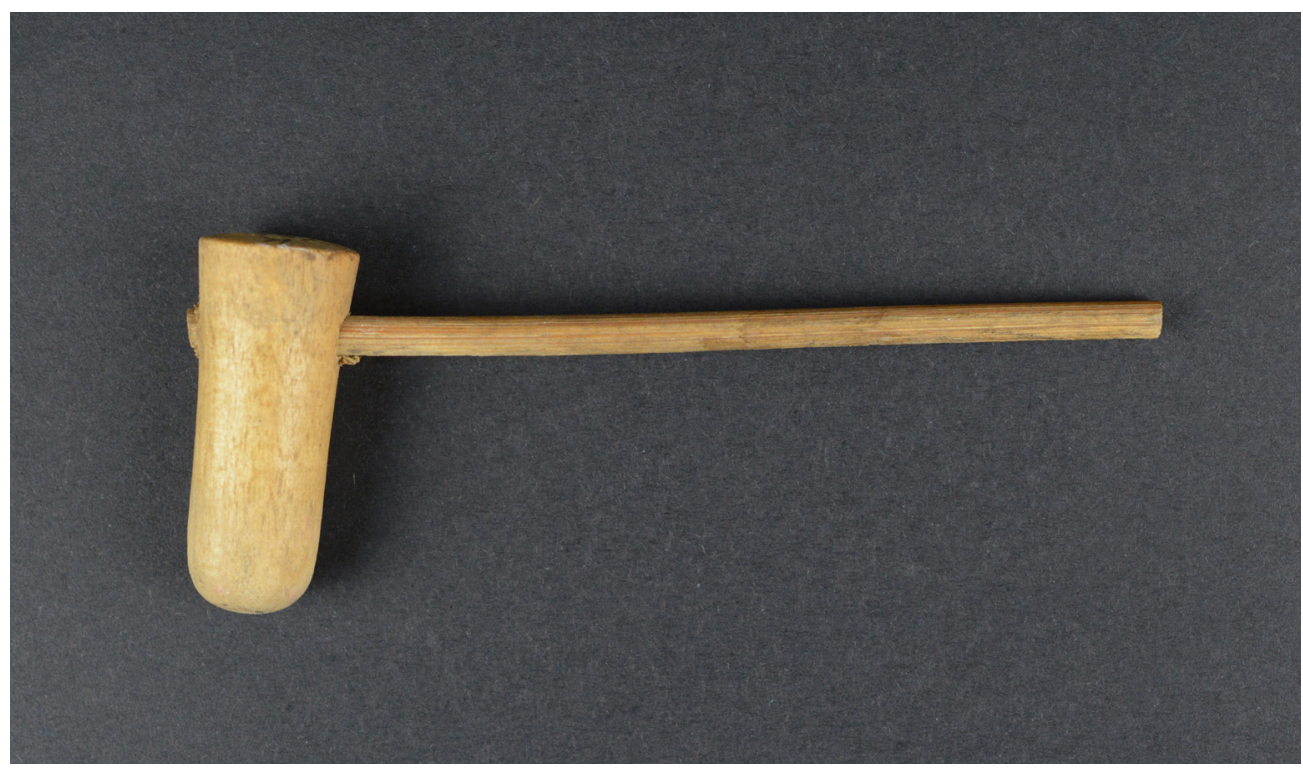

Figure 8. A miniature kine mallet. (Source: Alma Karlin Collection, Celje Regional Museum)

Since Alma Karlin was particularly interested in such small toys and miniature objects (see also Trnovec 2019,33-36), we still have to clarify which pieces (particularly of porcelain) are actually from Japan and belong to the kitchen set, and which ones are from other parts of the world, for example, Taiwan and other Southeast Asian cultures, and from Central America.

\section{d) Traditional Gift Wrappings}

Alma Karlin was interested in how Japanese people exchanged gifts with each other. She was obviously interested not only in what objects were favoured as gifts, but also in how these things were wrapped and presented. Among the small objects in her legacy we found the ceremonial paper strings mizubiki 水引, and an envelope with a printed symbol of noshi 尉斗.

Mizubiki are the decorative strings for gifts. High quality Japanese paper is cut in long strips and twisted into strings, dipped in the water in which rice has been washed (or thinned starch instead), and dried in the sun. These strings are then coloured into red, white, gold or silver. The name mizubiki comes from using the water after washing rice (mizu (water), biku (to lead, pull)). For gifts, the Japanese already started using the mizubiki strings instead of simple paper stripes around 
wrapped gifts in the Muromachi period (1336-1573). There are several rules in using the mizubiki: the string or the wrapping belt is usually composed of multiple mizubiki strings, a belt is composed of an odd number of strings for auspicious events, and an even number for misfortunes. There are also many different ways of tying the belt (Hendry 1993, 15-18).

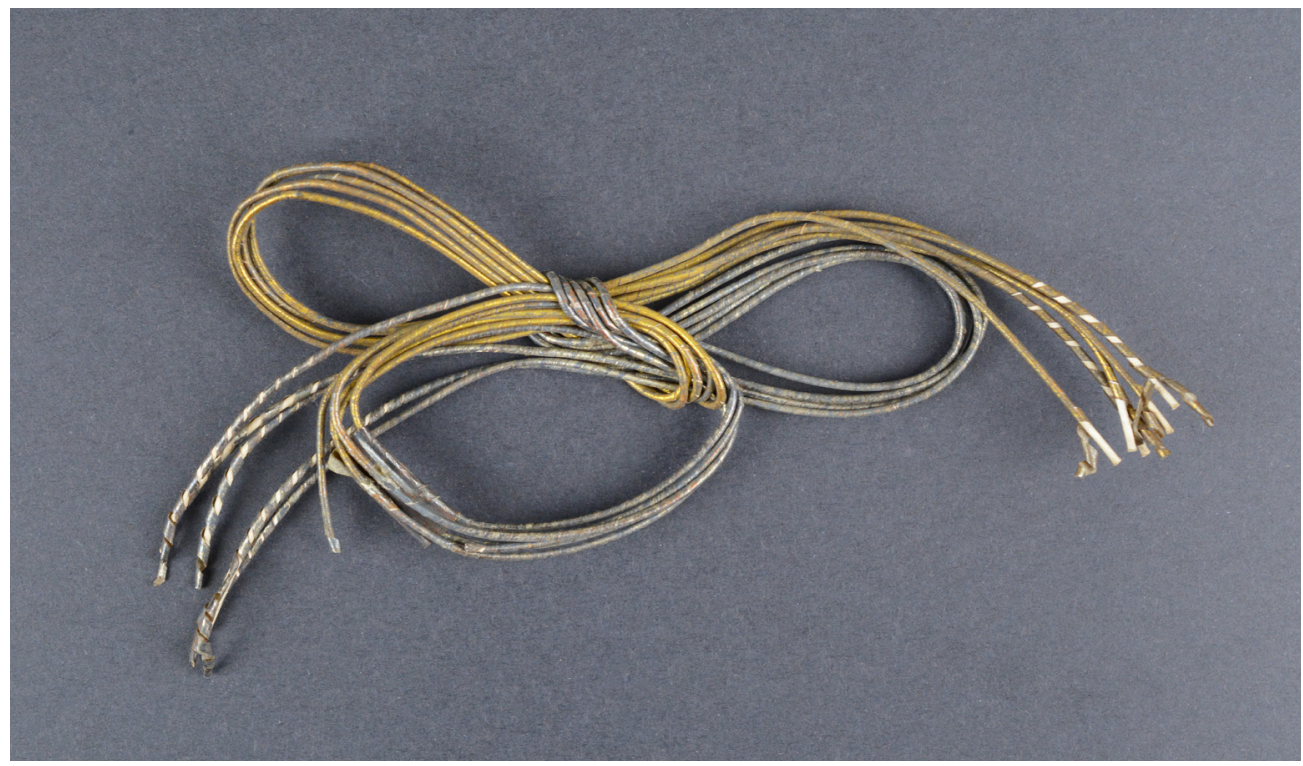

Figure 9. Mizuhiki strings. (Source: Alma Karlin Collection, Celje Regional Museum)

The mizubiki in Karlin's legacy is composed of five strings, so it was perhaps New Year or some happy festive occasion when this was used for some gift. The colour of individual strings has now faded, but some shining gold or pale red can be observed. At the end of strings the starched surface has come off and we can see the twisted paper. The knot used for regular festive occasion is partly recognisable.

The noshi envelope in Karlin's collection is of the kind used for giving money on various occasions. These printed envelopes are available in any stationery shops today, and we can see that this was already the case in the Taishō period. The print depicts the mizubiki strings together with the symbolic decoration of noshi for festive occasions.

"Noshi" is an abbreviation of "noshi awabi". Awabi (鮑 (abalone, the edible shellfish)) was a symbolic seafood which the Japanese attached to gifts. In the Buddhist tradition, no meat was enjoyed, including shellfish, but for other gifts outside the Buddhist tradition thinly sliced abalone pieces (noshi awabi) were enclosed. This 
symbolic attachment of a piece of yellow paper, instead of real abalone, wrapped in red and white pieces of paper, meant that it was intended for a happy occasion, and no misfortune.

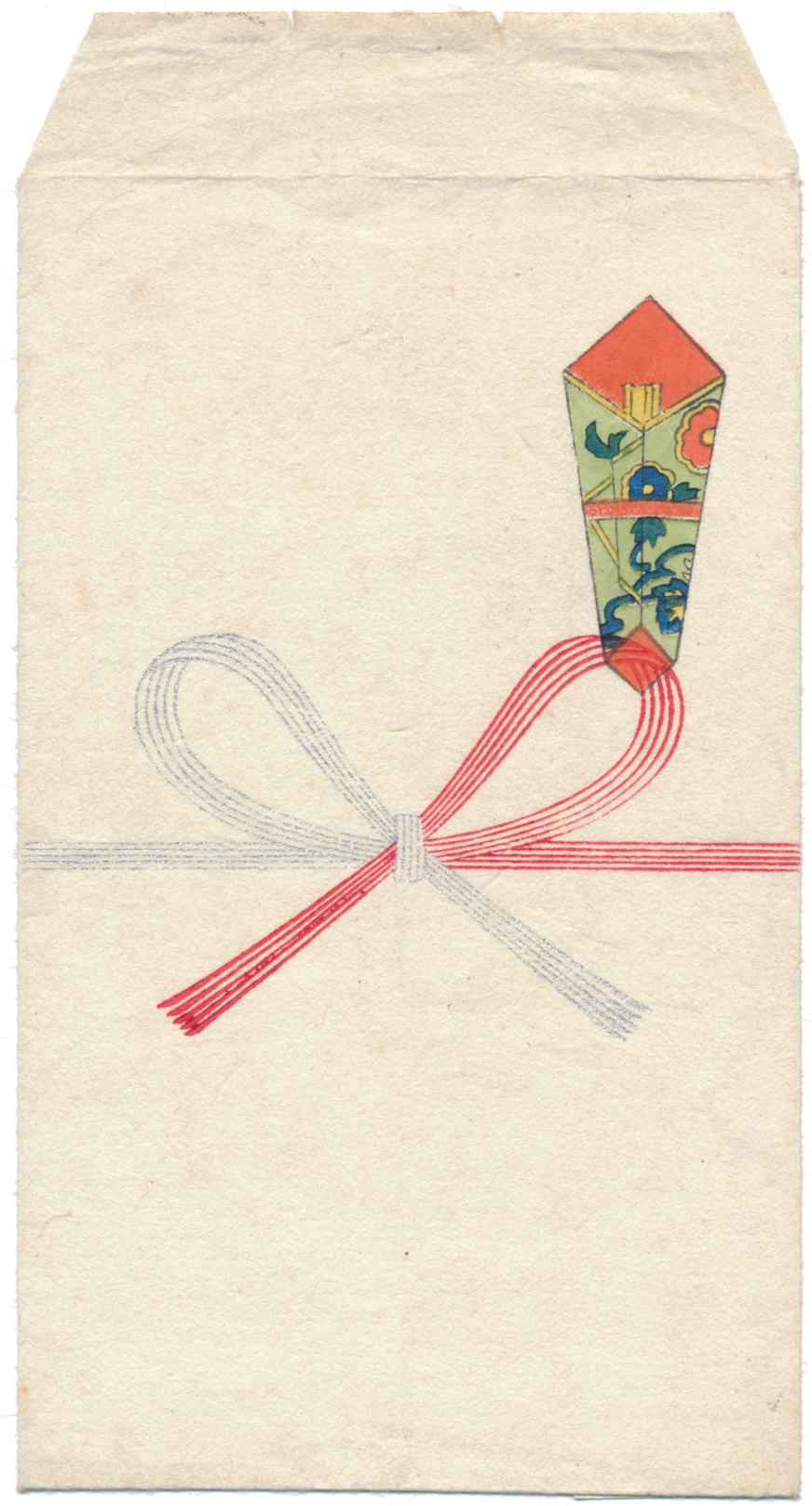

Figure 10. Noshi envelope. (Source: Alma Karlin Collection, Celje Regional Museum) 
The envelope in Karlin's collection is a regular-sized envelope called a shügi bukuro 祝儀袋, a special envelope for presenting a monetary gift or a tip. It is a usual practice in Japan to use such envelopes at celebrations, for example at a wedding. Everything is printed on this envelope: in the middle the mizubiki in red and silver, on the upper right hand corner the noshi, a piece of abalone wrapped in two-layered pieces of paper, red on the inner side, light green with some flowers outside. According to Japanese tradition the giver's name and the occasion are written on the envelope. There is no writing on the envelope in Karlin's collection, so we do not know if this envelope was actually used for some specific occasion. Alma Karlin saved this envelope as an example and reminder of the Japanese custom of giving money. On the reverse of this envelope we can see her handwritten memo in German: Geschenkkuvert mit Noshi (gift envelope with Noshi).

Karlin clearly realised that an example of such an envelope would serve as a good "souvenir", or a reminder of the unique Japanese culture as she witnessed it.

Knowledge about the traditional Japanese custom of wrapping and sending gifts was important to identify these objects, and the written information on the envelope confirms the fact that Karlin correctly understood this tradition, most probably with a help of a Japanese intellectual who explained it to her along with certain important concepts such as noshi.

\section{e) A kiri Box Cover}

The wooden board with some writing on the surface, found in Karlin's collection, is actually the top cover of some wooden box in which something important was stored, called in Japanese kiri no hako 桐の箱 (a box made of the princess tree or Paulownia tomentosa). The kiri wood or the princess tree is treasured in Japan since this material, among all kinds of wood, is the lightest, hard to break or burn, protects anything stored inside from moisture, and the grain is beautiful. This wood is typically used for furniture and storage boxes, and also for a musical instrument, the koto. A Japanese-style closet with drawers (tansu 䈍笥), made wholly of kiri wood, has long been an important element of the bride's dowry.

The writing on this piece of board says:

hakama, Taishō 4/5?, November

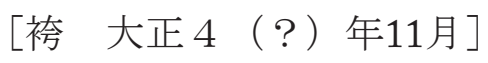

This board seems to have been the top cover of a wooden box which stored a pair of Japanese trousers, hakama 袴. This must have been a ceremonial clothing made 
in the year Taishō 4 or 5 (1915 or 1916). We have to first find out if there is the bottom part of this wooden box in Karlin's legacy. And if there is no bottom part of the box nor the contents of the box (the traditional Japanese-style trousers), we have to conclude that Alma Karlin was perhaps aware of the special Japanese custom of storing special (ceremonial) clothing in such wooden boxes and wanted to have a piece of such a box to include in her collection. We should be also aware of the small size of this board: $21.4 \mathrm{~cm} \mathrm{x} 11.1 \mathrm{~cm} \mathrm{x} 1.2 \mathrm{~cm}$. It is thus doubtful if a regular pair of trousers could be stored in a box with this small cover. Perhaps the box was meant for a small doll's trousers?

In case of this wooden board, the traditional custom in Japan was extremely important to identify the object. Without the words written on the board in the certain traditional manner, it may have been completely ignored and its function as the cover of a box remained unknown.

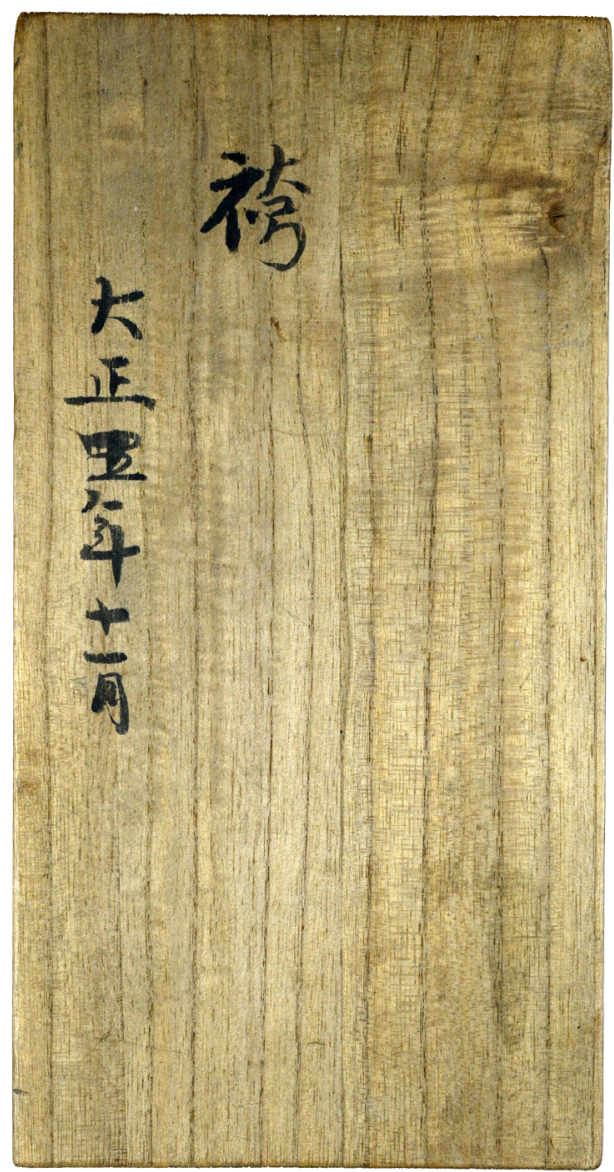

Figure 11. Wooden box cover. (Source: Alma Karlin Collection, Celje Regional Museum) 


\section{f) Two Bookmarks with an Envelope}

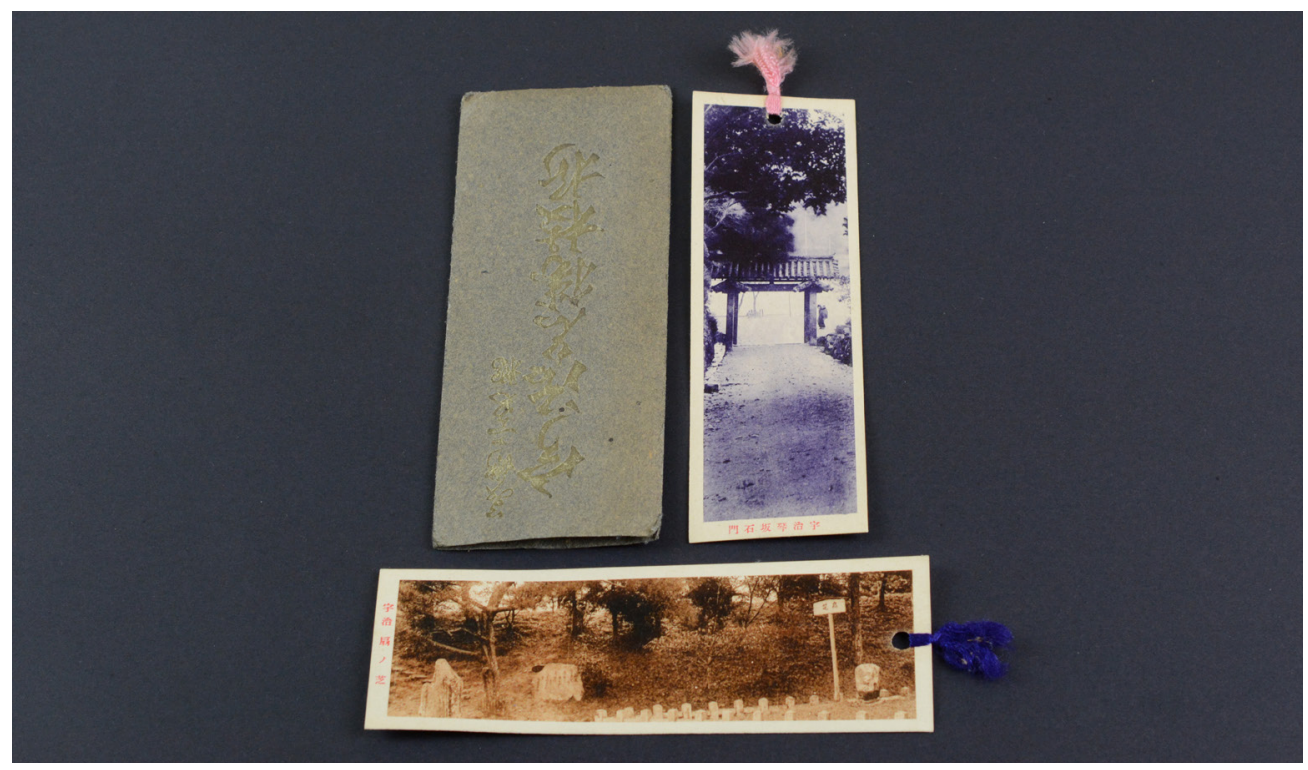

Figure 12. Bookmarks from Uji (Source: Alma Karlin Collection, Celje Regional Museum)

In Karlin's collection there are also two bookmarks. Similar to the numerous picture postcards in the collection, the bookmarks are photographs of historical sites, in this case the Uji Kotosaka Ishimon 宇治琴坂石門 (the stone gate of Uji Kotosaka) and Uji Ögi no Shiba 宇治扇の芝 (the lawn in the form of a fan in Uji). The place names are printed in Japanese, next to each of the black and white photos. The stone gate at the bottom of the slope Kotosaka is one of the gates of the temple Kōshōji 興聖寺, built in the year 1233. The slope is particularly known for its beauty in the autumn when the maple leaves change their colours. The $\bar{O}_{g i}$ no shiba lawn is a part of the historical and architectural site, Hōōdo 鳳凰堂. The elegant architecture in the form of a phoenix ( building in the temple Byōdōin 平等院, established in 1052 and today a world heritage site. In the year 1180, at the beginning of the conflict between the Taira and Minamoto clans in Japan, it is said that Minamoto no Yorimasa 源頼政, knowing that there was no way to escape from Taira no Tomomori 平知盛 who chased him to get his head, killed himself on this lawn. Therefore, this lawn is visited by Japanese tourists even today in memory of the warrior, Yorimasa (11041180). The photo on the bookmark also shows some small stone monuments dedicated to him (Soto Zen; Ōgi no Shiba). 
Alma Karlin usually made her own notes on the back of each postcard, if the card was not used and kept in her collection. In the case of her postcards from Kyōto, her notes on their reverse sides are very brief. ${ }^{6}$ However, the section "In Kyōto" of her travelogue, placed after the section "Sayonara" (description of her departure from Japan, or from Tōkyō), mainly writes about Uji (Karlin 2006, 270), the place of these two bookmarks, some $20 \mathrm{~km}$ south of the centre of Kyōto. In the travelogue Karlin does not mention any actual names of historical figures or old temples, but mentions the ancient Fujiwara clan and "buildings in the form of a phoenix spreading its wings". It is thus assumed, that Karlin did visit Kyōto and other places in the southwest of Japan, but rather briefly after saying goodbye to the German Embassy and her acquaintances in Tōkyō. (Shigemori Bučar 2019, 28). Based on Karlin's writing, we can assume the existence of a Japanese intellectual who accompanied and informed her about the meaning of the Heian period in relation to the city of Kyōto and its surroundings. On the reverse of both bookmarks we see Karlin's handwriting in pencil:

Tor des Koshoji-Tempels (Gate of the Kōshōji Temple)

Samurai Yorimasa nach seiner Niederlage gegen die Familie Heike beging hier Selbstmord.

(The samurai Yorimasa committed suicide after his loss against the family Heike.)

Karlin's handwritten notes show that she was correctly informed of the historical details of the places she visited. We can even feel a part of someone's intention of how and with which visits to explain some details of Japanese history.

\section{g) Envelopes of Picture Postcard Sets}

Another interesting characteristic of Alma Karlin's collection, in relation to the numerous picture postcards, is that she (and the subsequent keepers of her collection) took care of the envelopes of various series of postcards. So far we have found eight such envelopes, as follows, with the number in parenthesis showing how many postcards are in the set, whenever known:

1) Jōge Hachiri 上下八里 (Hakone);

2) Ise Meisho 伊勢名所 “Ise and Futami”;

6 Wieder ein Tempel. / Auch ein Tempel in Kioto. / Kinkaku-tempel / Der Heiantempel in Kioto (Shigemori Bučar 2019, 31). 
3) “Farmers Life at Japanese Country” 田舎の生活 (10);

4) “Kyoto Viewes (sic!)”京都名勝 (10);

5）大正十年四月二十日通信事業創始五十年記念絵葉書 （2）（Commemorating the 50th Anniversary of the Postal Communication);

6) Tokyo Meisho 東京名所 (handwritten in pencil: 16 cards??);

7）日光中禅寺情趣 “Souviner (sic!) of Nikko”;

8) 東宮殿下臺湾行啓記念 (Commemorating his Imperial Highness the Crown Prince's Visit to Taiwan).

Among them, the most interesting and informative in relation to the time of Karlin's sojourn in Tokyo are the two envelopes for historical commemorations (Numbers 5 and 8 above). Publication of commemorative postcards became popular in Japan after the Russo-Japanese War in 1904/1905 (Satō 2002, 39-41).

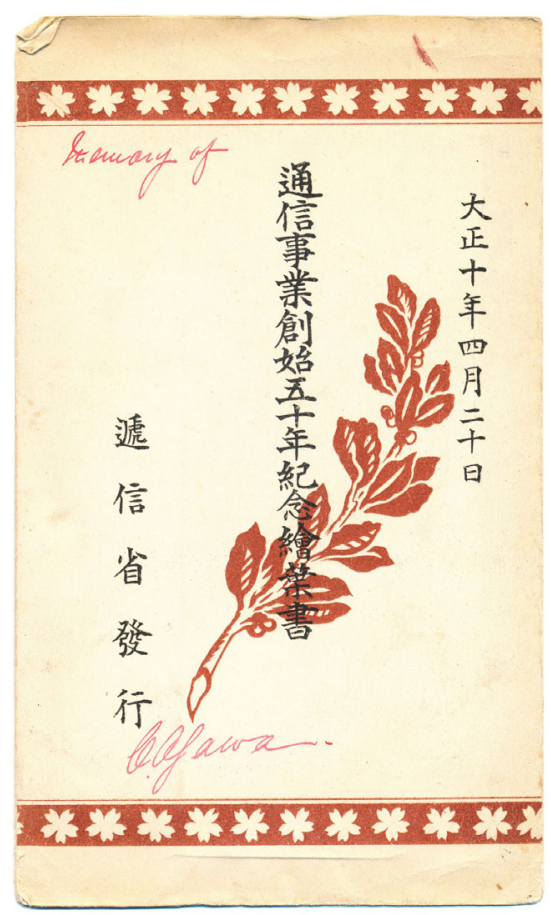

Figure 13. 50th Anniversary of Postal Communication. (Source: Alma Karlin Collection, Celje Regional Museum) 


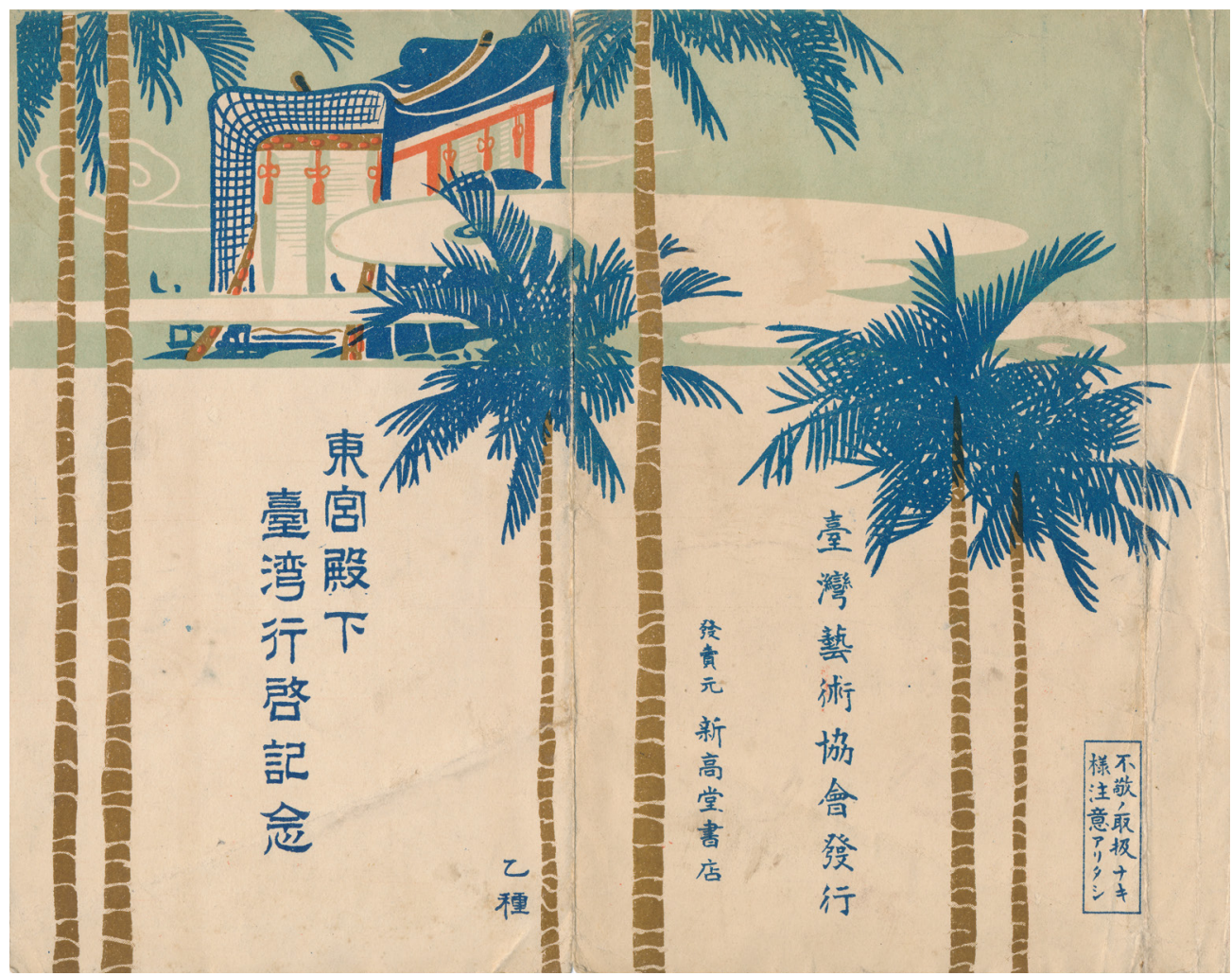

Figure 14. Crown Prince's visit to Taiwan. (Source: Alma Karlin Collection, Celje Regional Museum)

The 50th anniversary of modern Japanese postal communication was celebrated in the 10th year of the Taishō period, i.e. one year before Karlin arrived in Japan. We can see that Karlin received this set of postcards as a gift, as it is handwritten on the envelope from a person with the name Ogawa (?).

The Crown Prince (later Emperor Hirohito of the Shōwa period) visited Taiwan in April 1923. That was when Alma Karlin was still staying in Tōkyō, but she later visited Taiwan in the same year, so she either already possessed a series of postcards from Taiwan while in Japan, or acquired it later when she herself visited Taiwan. There was great public interest in the Crown Prince's visit, particularly because Taiwan was under the Japanese rule between 1895 and 1945. The picture postcards for this occasion were published by the Taiwan Art Association 臺湾藝 術協会, as printed on the envelope. 


\section{Trivial Objects: Characteristics and Significance}

The types of objects in a collection suggest the particular interests of the collector, their way of thinking and values.

As for the small and seemingly trivial objects considered in this paper, their characteristics can be summarised as small in size, light in weight, inexpensive, and parts of a whole. At least in relation to these physical characteristics, these objects may be called "trivial" in the sense of "(seemingly) insignificant". We can assume that they were included in the collection because of practical reasons, as they could be brought home without posing any great transport problems.

However, we must also consider the significance of these small objects. Karlin purchased the tram ticket in order to go to her workplace. A receipt issued by a newspaper house is also in the collection, since Karlin most probably had some close connection to this payment, and thus the piece of paper meant something special to her. As for picture postcards, they were very popular in Japan and Asia in general towards the end of 19 th century and the first decades of the 20th. Karlin was also an eager collector of postcards of the touristic sites she visited, and they were cheap and readily available at the time of her journey in Asia. As a writer, she used some of these postcards to illustrate her texts. And we are convinced that she also bought the paper bookmarks from Uji, the place which she describes also in her travelogue, for much the same reasons. As for other trifles, we can imagine that they were acquired as gifts, such as the wall calendar and New Year greeting card, most probably given by her students or acquaintances.

Moreover, we can also notice, at least with some of the small objects collected in Japan, that Karlin was particularly interested in the traditional customs of the nation, such as how to wrap and exchange gifts, and how to store ceremonial clothes. Karlin had a strong urge to acquire new knowledge, and a particular ethnological interest in people's lives. Her interest was thus different to the Japonisme which was, at that time in the 1920s, perhaps already out of fashion.

\section{Conclusion}

The collection of Alma M. Karlin in the Regional Museum of Celje consists of many small objects of personal interest, the "souvenirs" of a female adventurer who had first-hand experience of life in Japan, mostly in the middle of the capital city of Tōkyō in the interwar years. 
They were thus to the collector herself reminders of her personal experience. As we have seen in the definitions of "collecting" and "souvenirs", the activity of choosing what to collect and bring home is a subjective matter. It was perhaps also Karlin's intention that she would eventually reveal more details of some of her souvenirs in her writing and/or exhibitions which she never realised.

And why are these trivial items interesting for us? They faithfully narrate the details of the traditional customs and popular culture of Japan exactly in the years 1922 and 1923, the 11th and 12th years of the Taisho period, more than 60 years after the country opened itself to the world. The Russo-Japanese War was already history, and the society was rapidly developing and the people's lives were rather liberal and democratic. The capital city enjoyed its modernity, peace and the harmonious coexistence of tradition and new ways of life, although this was soon to be interrupted by the Great Kantō Earthquake, which hit Tōkyō in September 1923, just a few months after Karlin had left Japan and continued her journey to Korea and China.

These small objects in Karlin's collection are certainly "souvenirs", that is, Karlin's personal choice of what to remember from her daily life in Japan. For viewers of the museum collection, they may seem to be a set of somewhat random items, for souvenirs are the authentication of a traveller's unique experience. The true value of these "insignificant and trivial" objects from Japan, when the collector is not the owner anymore, lies in the hands of museum visitors and curators. This collection is probably the only one in Slovenia to teach us the small details of life in Taishō Japan, through the eyes of the person who actually experienced it. Some items reveal Karlin's sharp ethnographic eyes for the traditional customs of Japan (the ceremonial wrappings, kiri box cover), others tell us of very contemporary things towards the end of Taishō period, that perhaps even Karlin herself was not aware of (the Kewpie postcard, the receipt format, memorial postcard envelopes).

It is also worth noting and admiring the fact that the small, trivial and seemingly insignificant objects, such as paper strips and pieces of wood, were carefully and faithfully conserved in the collection of Alma Karlin's legacy in the museum. This collection, as it is known to us at present, gives us quite detailed information about life in Japan, mainly in the capital city of Tōkyō, in the years 1922 and 1923.

\section{Acknowledgement}

The research for this paper was carried out as part of the project East Asian Collections in Slovenia: Inclusion of Slovenia in the Global Exchanges of Objects and Ideas with East Asia (2018-2021) (no. J7-9429), funded by the Slovenian Research Agency. 


\section{References}

Alsop, Joseph. 1982. The Rare Art Traditions: A History of Collecting and Its Linked Phenomena. New York: Harper 8c Row.

Aristides, N. 1988. "Calm and Uncollected." American Scholar 57 (3): 327-36.

Belk, Russell. 2006. "Collectors and Collecting." In Handbook of Material Culture, edited by Christopher Tilly et al., 534-45. London, Thousand Oaks, New Delhi: SAGE Publications.

Berdajs, Tina. 2019. "Researching the Origins of an Ink Stone from the Collection of Alma M. Karlin.” Asian Studies 7 (2):269-83. https://doi.org/10.4312/ as.2019.7.2.269-283.

Digital Dai-ji-sen Plus. 2019a. キューピー (Kerwpie). Accessed January 31, 2021. https://japanknowledge-com.nukweb.nuk.uni-lj.si/lib/en/ display/?lid=5091000733440.

—.2019b.キユーピー(Kewpie).AccessedJanuary31,2021.https://japanknowledge-com.nukweb.nuk.uni-lj.si/lib/en/display/?lid=5091000733450.

Ehagaki Shiryōkan 絵葉書資料館 (Postcard Museum). n.d. Accessed February 1, 2021. https://www.ehagaki.org/, https://www.ehagaki.org/?s=キューピー.

Hendry, Joy. 1993. Wrapping Culture: Politeness, Presentation and Power in Japan and Other Societies. Oxford: Clarendon Press.

Karlin, Alma. 1969. Samotno potovanje. Ljubljana: Mladinska knjiga. . 1997. Popotne skice. Kmečki glas: Ljubljana.

—_. 2006. Samotno potovanje v daljne dežele: tragedija ženske. Celje: Mohorjeva družba.

Ōgi no Shiba, Minamoto Yorimasa shūen no chi 扇の芝・源頼政終焉の地 (The Lawn in a Fan Form, The place Yorimasa ended his Life). Accessed February 1, 2021. https://www.yoritomo-japan.com/nara-kyoto/byodoin/byodoin-ouginosiba.html.

Pearce, Susan M. 1994. “The Urge to Collect." In Interpreting Objects and Collections, edited by Susan M. Pearce, 157-59. London, New York: Routledge.

Potts, Rolf. 2018. Souvenir. New York, London: Bloomsbury.

Satō, Kenji. 2002. "Postcards in Japan: A Historical Sociology of a Forgotten Culture.” In International Journal of Japanese Sociology 11: 35-55.

Shigemori, Chikako. 2016. "Surovenia kyōwakoku hokan no ehagaki korekushon ス ロヴェニア共和国保管の絵葉書コレクション (Picture Postcard Collections in the Republic of Slovenia)." In Nibon teikoku no byōshō seisei, kioku, keishō日本帝国の表象 生成・記憶・継承 (Representation of the Japanese Empire: Formation, Memories and Inheritance), edited by Mijeoung Park, and Rei Hasegava, 219-44. Tokyo: Enishi Shobô. 
—. 2019. "Alma M. Karlin's Visits to Temples and Shrines in Japan." Poligrafi: revija za religiologijo, mitologijo in filozofijo 24 (93/94): 3-48.

—. 2020a. "Alma Karlin in Korea: Observation of the Land and its People by an Adventurer from Slovenia." In Koreans and Central Europeans, vol. 3, Informal Contacts up to 1950, edited by Andreas Schirmer, 207-22. Vienna: Praesens Verlag.

—. 2020b. "Spominki in spomini na bojevnike - primer kozuke." Ars E̋ bumanitas: revija za umetnost in bumanistiko 14 (2): 87-101.

Shogakukan Random House Japanese-English Dictionary. 2020. “Kewpie.” Accessed January 31, 2021. https://japanknowledge-com.nukweb.nuk.uni-lj.si/lib/en/ display/?lid=40010RH094212000.

Soto Zen/Buttokuzan. KOSHOJI. Kōshōji, Sōtōshū 興正寺、曹洞宗. Accessed February 1, 2021. https://www.uji-koushouji.jp/sightseeing.html.

Stanonik, Janez. 1983. “Alma Maximiliana Karlin.” In Australian Papers, edited by Mirko Jurak, 41-48. Ljubljana: Faculty of Arts.

Trnovec, Barbara. 2011. Kolumbova bči: življenje in delo Alme M. Karlin. Celje: Pokrajinski muzej Celje.

—. 2020. "Kaj vse bom na poti odkrila, kaj prinesla s seboj!: potovanje in zbirka Alme M. Karlin (What I Will Discover along the Way, What I Will Bring with Me!: Journey and the Collection of Alma M. Karlin).” Ars E Humanitas 14 (2): 61-71.

Trnovec, Barbara et al. 2019. Azija me je povsem uročla: katalog občasne razstave ob 130. obletnici rojstva Alme M. Karlin in 100. obletnici njenega odhoda na pot okrog sveta (Asia Utterly Bewitched Me: Catalogue of the Temporary Exhibition Marking the 130th Anniversary of Alma M. Karlin's Birth and the Centenary of her Departure on her Journey around the World). Celje: Pokrajinski muzej; Ljubljana: Znanstvena založba Filozofske fakultete.

Utagawa, Kuniteru 歌川国輝. n.d. “Ishokujū no uchi kashoku osana etoki no zu「 衣喰住之内家職幼絵解之図」(Illustrations of Clothing, Food and Homes for Children: House-Building Workers).” In Dai-go ueki-ya, sakan 「第 五 植木屋・左官」(No. 5: Gardners and Plasterers). National Institutes for the Humanities. Accessed January 31, 2021. https://ja.ukiyo-e.org/image/ metro/086-006-23.

Veselič, Maja. 2021. "Collecting Heads: Taiwanese Indigenous People, the Japanese Colonial Photographs and the Postcard Collection of Alma M. Karlin.” Forthcoming.

Yamaji, Katsuhiko 山路勝彦. 2009/2010. “日英博覧会と「人間動物園」Nichi-ei hakurankai to 'ningen dōbutsuen' (The Japan-British Exhibition and the Idea of 'Human zoos')." Journal of the School of Sociology 108: 1-27. Kwansei Gakuin University Repository. http://hdl.handle.net/10236/3255. 